\title{
The importance of clinical, histopathological and immunohistochemical marking for differential diagnosis of non-hematopoietic gastrointestinal mesenchymal neoplasms in dogs: literature review
}

\section{Importância da avaliação clínica, anatomopatológica e imuno-histoquímica para o diagnóstico diferencial das neoplasias mesenquimais gastrointestinais não hematopoiéticas em cães: revisão de literatura}

\author{
Rafael Magdanelo LEANDRO ${ }^{1}$; Fernando de Paula FREITAS²; Lilian Rose Marques de SÁ ${ }^{3}$ \\ ${ }^{1}$ Universidade de São Paulo, Faculdade de Medicina Veterinária e Zootecnia, Departamento de Cirurgia, São Paulo - SP, Brazil \\ ${ }^{2}$ Universidade Anhanguera, Hospital Veterinário, Departamento de Cirurgia, São Paulo - SP, Brazil \\ ${ }^{3}$ Universidade de São Paulo, Faculdade de Medicina Veterinária e Zootecnia, Departamento de Patologia, São Paulo - SP, Brazil
}

\begin{abstract}
Gastrointestinal neoplasms in dogs represent a challenge for the veterinary clinician and surgeon as they are mostly malignant and when the owner notices the primary clinical changes the disease may already be in an advanced stage. Due to the high clinical and histopathological similarity between mesenchymal gastrointestinal neoplasms, it is often impossible to establish the definitive morphological diagnosis using light microscopy alone. In addition, there are only a few articles describing the anatomopathological and immunohistochemical characteristics, which make its complete characterization urgent and relevant in our context in order to assist the veterinary clinician, surgeon, and pathologist in establishing a precise diagnosis of these tumors.
\end{abstract}

Keywords: C-KIT. Sarcoma. Stomach. Intestine. Colon. Rectum.

\section{Resumo}

As neoplasias gastrointestinais em cães representam casos desafiantes ao clínico e cirurgião, pois são em sua maioria malignas e, quando as primeiras alterações clínicas são notadas pelo proprietário do animal, a doença pode estar em estágio de desenvolvimento muito avançado. Devido à elevada similaridade clínica e histopatológica entre as neoplasias gastrointestinais mesenquimais, muitas vezes não é possível estabelecer o diagnóstico morfológico definitivo apenas com a microscopia de luz. Acrescenta-se que são poucos os artigos que descrevem as características anatomopatológicas e imuno-histoquímicas das neoplasias mesenquimais gastrointestinais que acometem os cães, o que torna premente a caracterização destas em nosso contexto, com o intuito de auxiliar clínico, cirurgião e patologista veterinário a estabelecer o diagnóstico destes tumores.

Palavras chave: C-KIT. Sarcoma. Estômago. Intestino. Cólon. Reto.

Correspondence to:

Lilian Rose Marques de Sá

Universidade de São Paulo, Faculdade de Medicina Veterinária

e Zootecnia, Departamento de Patologia

Av. Prof. Dr. Orlando Marques de Paiva, 87 - Cidade

Universitária

CEP 05508-270, São Paulo, SP, Brazil

e-mail: lilianrms@gmail.com

Received: 25/03/2017

Approved: 10/07/2017

The non-hematopoietic gastrointestinal mesenchymal neoplasms present a great challenge to the veterinarian, since they present incipient evolution, nonspecific clinical alterations, and high histomorphological similarity (GUILFORD; STROMBECK, 1996). These general characteristics make the early and definitive diagnosis difficult, because when the owner recognizes the first clinical manifestations, these types of neoplasm usually are in advanced development stage (WASHABAU, 2013; LEANDRO; SÁ, 2015). Early diagnosis may increase the therapeutic options and ultimately the patient's survival and quality of life (LEIBMAN et al., 2003). Thus, the purpose of this review is to provide relevant and modern 
information in order to assist the clinician, surgeon, and veterinary pathologist in setting the definitive diagnosis of non-hematopoietic gastrointestinal mesenchymal neoplasms in dogs.

Most gastrointestinal tract primary neoplasms are malignant and account for approximately $2 \%$ of all canine neoplasms; these diseases may be of epithelial, neuroendocrine, hematopoietic, and non-hematopoietic mesenchymal origin (BETTINI et al., 2003). The nonhematopoietic mesenchymal gastrointestinal neoplasms comprise $16 \%$ of all neoplasms of the digestive system, mainly affecting the large intestine with the cecum being the most affected site (BETTINI et al., 2003; CERIEL et al., 2007). The prevalence of colonic and rectal tumors in dogs is 2.8 to 4.1 for 10,000 dogs in the United States of America (LEIBMAN et al., 2003; RUSSEL et al., 2007). There are no studies with this type of information in Brazilian literature, but male dogs are the most affected and present a mean age of 9.8 years at the time of diagnosis (WASHABAU, 2013).

Breeds such as West White Highland Terriers, Chow Chow, Collie, American Staffordshire Terrier, German Shepherd, Maltese, and Bull Terrier are predisposed to develop gastrointestinal neoplasms (GUILFORD; STROMBECK, 1996; LEIBMAN et al., 2003; LEANDRO; SÁ, 2015). Approximately $40 \%$ of the dogs with nonhematopoietic gastrointestinal mesenchymal neoplasms exhibit the average survival time of 12 months (CRAWSHAW et al., 1998). This parameter is influenced by anatomical lesion location, size of the neoformation, presence or absence of metastases, and compromised or free surgical margin. These criteria are fundamental for the veterinarian to take into consideration in order to estimate the prognosis of each case (BETTINI et al., 2003; CERIEL et al., 2007).

Macroscopically, such neoplasms are large, irregular nodular formations ranging from 2.5 to 30 $\mathrm{cm}$ in diameter, mainly affecting the mucosa, muscular layer, and the anti-mesenteric border of the intestinal segments (LANGENBACK et al., 1998; FROST et al., 2003; CERIEL et al., 2007; RUSSEL et al., 2007). The morphological characteristics are proliferation of fusiforms to polygonal and sometimes epithelioid cells, located in the gastrointestinal wall tract (MIETTINEN; LASOTA, 2001; FLETCHER et al., 2002; HAYES et al., 2013). In this group are included gastrointestinal stromal tumor (GIST), leiomyomas (LM), leiomyosarcomas (LMS), peripheral nerve sheath tumors (PNST), osteosarcomas, and undifferentiated sarcomas (LANGENBACK et al., 1998; BETTINI et al., 2003; FROST et al., 2003; CERIEL et al., 2007).

Studies using genetic and immunohistochemical markers have revolutionized the diagnosis of mesenchymal neoplasms in human and veterinary medicine, since it has become possible to classify the origin of neoplasias, allowing a better understanding of their biological behavior, epidemiology, and clinical presentation, sometimes allowing specific treatment (CERIEL et al., 2007; HAYES et al., 2013). In the recent past all cases of gastrointestinal mesenchymal neoplasia were considered sarcomas which carried poor prognoses, besides that all types were treated clinically and therapeutically in a similar manner (CERIEL et al., 2007; HAYES et al., 2013).

\section{Main clinical presentation in dogs with gastrointestinal neoplasms}

Clinical presentation in dogs with gastrointestinal tumors include slow progressive gastrointestinal manifestations that do not indicate the histomorphologic origin of the neoplasia, but may lead the clinician to the affected region of the gastrointestinal tract (GUILFORD; STROMBECK, 1996; LEIBMAN et al., 2003; RUSSEL et al., 2007). Non-gastrointestinal clinical signs, such as anemia, ascites, polyuria / polydipsia, may also be associated with these tumors (COHEN; POST, 1999; CRAWSHAW et al., 1998; LEIBMAN et al., 2003; LEANDRO; SÁ, 2016).

The involvement of the proximal segments of the gastrointestinal tract, such as the stomach and duodenum, are related to manifestations of emesis, melena, anorexia and abdominal distension (LEIBMAN et al., 2003). Hematemesis occurs in more than $50 \%$ of dogs with gastric neoplasms and is due to mucosal ulcers, hemorrhages, stenosis, and obstructions located in the gastric body and / or pylorus (LEANDRO; SÁ, 2015). Diarrhea is a common clinical change in neoplasms located in jejunum and ileum, whereas dyskinesia and hematochezia are often associated with neoplastic involvement in cecum and colon (LEANDRO; SÁ, 2015). Tenesmus and rectal prolapse are manifestations that are related to neoplasms located in the rectum (LEIBMAN et al., 2003; WASHABAU, 2013). The neoplasias located in the cecum present a greater chance of developing intestinal rupture and septic peritonitis, compared to neoplasias in the small intestine (CERIEL et al., 2007).

Nonspecific clinical signs of the gastrointestinal tract also occur and need to be considered, such as: 
hyporexia, weight loss, abdominal pain, and peritonitis (GUILFORD; STROMBECK, 1996; LEANDRO; SÁ, 2015). Paraneoplastic syndromes, anemia, clinical alterations due to intestinal obstruction, and malabsorption may be associated with gastrointestinal neoplasia (LAROCK; GINN, 1997; COHEN, POST, 1999; CRAWSHAW et al., 1998; LEANDRO; SÁ, 2016). The clinician and surgeon need to consider among the differential diagnoses the ulceroproliferative processes of inflammatory bowel disease, gastrointestinal infectious processes and other gastrointestinal neoplasms, such as lymphoma and adenocarcinoma (TURK et al., 1981; HEAD et al., 2002).

In some patients it is possible that abdominal palpation indicates the presence of increased intra-abdominal volumes and radiographic and / or ultrasonographic evaluation guides the clinician for the possibility of a neoplastic gastrointestinal process (HANAZONO et al., 2012; CONSTANT; POLF 2015).

\section{Gastrointestinal Stromal Tumor (GIST)}

GIST is the most common mesenchymal neoplasm of the gastrointestinal tract, accounting for 50 to $60 \%$ of the cases in dogs (CERIEL et al., 2007). There is also a description of GIST in horses, non-human primates, and humans (HAYES et al., 2013; IRIE et al., 2015; LEANDRO, SÁ, 2015).

GISTs occur, in $48 \%$ of the cases, mainly located in the large intestine (LI), followed by $29 \%$ in the small intestine (SI), $19 \%$ in the stomach, and $5 \%$ in the mesentery (FROST et al., 2003). Cecum is the main site of involvement in dogs and the mean age at diagnosis is 10.7 years old. In this location GIST is associated with greater aggressive behavior and risk of intestinal perforation, peritonitis, and septicemia (CERIEL et al., 2007; IRIE et al., 2015).

From the morphological point of view, four morphological patterns of GIST are described in dogs and in men, although the patterns can be mixed in the same tumor: storiform, myxoid, fascicular, and epithelioid (HEAD et al., 2002; HAYES et al., 2013; LEANDRO; SÁ, 2016). It is considered that the fascicular and estoriform patterns are the most frequent in humans, followed by the epithelioid and mixed patterns (MIETTINEN; LASOTA, 2001; ZAO; YUE, 2012). In dogs the fascicular pattern is the most common and in some cases a mixed pattern formed by the fusiform and epithelioid may be found (CERIEL et al., 2007; HAYES et al., 2013).

The fusiform GIST is composed of short interlaced fascicles of cells with elongate nuclei, eosinophilic and fibrillar cytoplasm, as shown in figures $1 \mathrm{~B}$. In some circumstances it may present patterns of neural differentiation, such as nuclei palisade stratification. The epithelioid pattern consists of nests or cords of cells with ovoid or rounded nuclei, presenting eosinophilic cytoplasm and being frequently present perinuclear cytoplasmic vacuoles. The stroma can be hyalinized or myxoid. When present, focuses of necrosis and hemorrhage may be associated with malignancy, a variable number of macrophages containing cytoplasmic hemosiderin granules distributed at the periphery of the neoplasm or between neoplastic cells (HEAD et al., 2002; CERIEL et al., 2007; RUSSEL et al., 2007; HAYES et al., 2013).
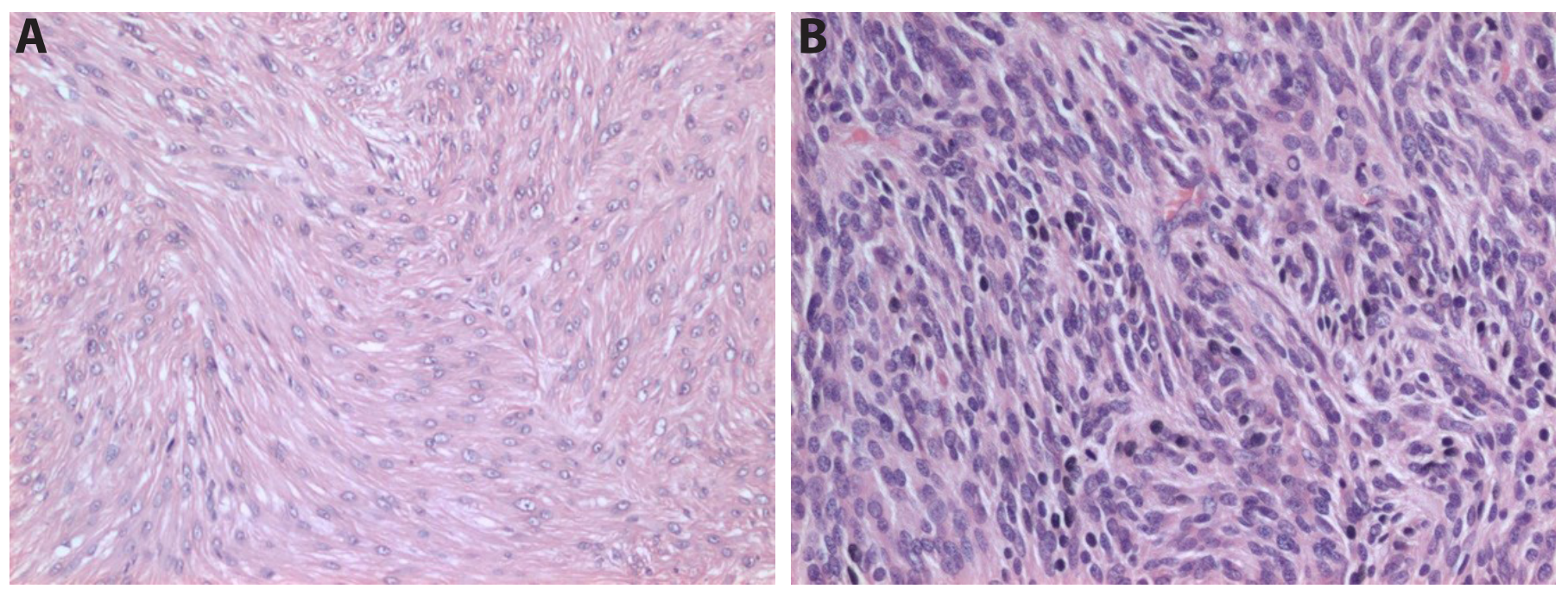

Figure 1 - Example of histomorphological similarity between intestinal sarcomas in dogs. A. leiomyosarcoma in the intestine; B. Gastrointestinal stromal tumor (GIST) in intestine, hematoxylin and eosin, 200x 
GISTs mainly compromise the submucosal and muscular layers, and may in some cases compromise all layers of the gastrointestinal tract (HAYES et al., 2013; LEANDRO; SÁ, 2016). Mitotic index is quite variable and allied to the macroscopic size of the tumor represents the main way of estimating the malignancy potential and aggressiveness of these neoplasms, both in humans and animals (HANAZONO et al., 2012; HAYES et al., 2013; LEANDRO, SÁ, 2016).

Some characteristics used in human medicine to assess the metastatic risk of GIST are presented in table 1, which was adapted from the information collected from the following authors (MIETTINEN; LASOTA, 2001; FLETCHER et al., 2002; ZAO; YUE, 2012). Based on this information, dogs with tumors larger than $5 \mathrm{~cm}$ with ultrasonographic features characterized by irregular surface and heterogeneous appearance with hypoechoic areas at the center of the tumor have a reserved prognosis and a greater risk of distant metastasis, whereas lesions smaller than $5 \mathrm{~cm}$ show a better evolution, with better survival rates (HAZAZONO et al., 2012).

Table 1 - Risks of aggressive behavior of GIST related to size and counting of mitotic figures in human neoplasms - São Paulo 2017 (adapted from FLETCHER et al., 2002)

\begin{tabular}{lcc}
\hline \multicolumn{1}{c}{ Risk of aggressive behavior } & Size & Count of mitosis figures \\
\hline Very low risk & $<2 \mathrm{~cm}$ & $<5 / 50$ fields of $400 \mathrm{x}$ \\
Low risk & $2-5 \mathrm{~cm}$ & $<5 / 50$ fields of $400 \mathrm{x}$ \\
Intermediate risk & $<5 \mathrm{~cm}$ & $6-10 / 50$ fields of $400 \mathrm{x}$ \\
& $<5 \mathrm{~cm}$ & $<5 / 50$ fields of $400 \mathrm{x}$ \\
High risk & $>10 \mathrm{~cm}$ & Any mitosis rate \\
& Any size & $>10 / 50$ fields of $400 \mathrm{x}$ \\
\hline
\end{tabular}

There is evidence of GIST metastasis due to hematogenous dissemination in 30\% of cases, with the liver, intestinal serous surface or abdominal cavity being the most frequent sites. However, bone and lung metastases are rare (FROST et al., 2003; CERIEL et al., 2007; HAYES et al., 2013). The mean survival rate of dogs with GIST submitted to the surgical procedure of mass removal, without adjuvant chemotherapeutic treatment is 11.6 months from the definitive diagnosis (CERIEL et al., 2007).

GIST has peculiar immunohistochemical and genetic characteristics that differentiate it from other gastrointestinal tract neoplasms (BETTINI et al., 2003). Immunohistochemical studies revealed that GIST can be classified according to differentiation in smooth muscle (myogenic), neural tissue (neurogenic), combination of both (mixed) or undifferentiated (anaplastic), justifying their difficult morphological diagnosis by traditional methods of microscopy (CERIEL et al., 2007; HAYES et al., 2013).

Regarding immunostaining, GISTs are 100\% positive for vimentin, and negative for epithelial cell markers such as cytokeratin AE1/AE3, and hematopoietic markers such as CD3 (T lymphocytes), CD20, and CD79 (B lymphocytes), as well as for the glial fibrillary acidic protein
(GFAP) (MIETTINEN; LASOTA, 2001; CERIEL et al., 2007; HAYES et al., 2013)

The immunohistochemical marker CD117 (c-KIT), which is the marker of choice for differentiating GIST, is present in up to $60 \%-70 \%$ of malignant GISTs in dogs, and shows diffuse and strong cytoplasmic immunoreactivity as represented by the figure $2 \mathrm{~A}$, being absent in primary neoplasms of muscular and nerve sheath origin (FROST et al., 2003; CERIEL et al., 2007; RUSSEL et al., 2007; HAYES et al., 2013). Thus, CD117 immunostaining is important for the definitive diagnosis and prognosis of this neoplasm.

In cases of malignant mesenchymal neoplasms of fusiform cells and negative c-KIT a further definitive diagnostic strategy option is the use of the DOG 1 antibody, which presents specificity and sensitivity in cases of GISTs and, thus, may be included in the immunohistochemical panel (LIEGL et al., 2009; DAILEY et al., 2015).

The immunoexpression of smooth muscle actin (SMA) and / or desmin are observed in normal and neoplastic smooth muscle cells, benign or malignant, and in some fibroblasts. A significant subset of GIST with myogenic differentiation is positive in 33\% - 40\% for SMA and $80 \%$ - 82\% for desmin (LAROCK; GINN, 1997; CERIEL et al., 2007; LIEGL et al., 2009; HAYES et al., 2013). 

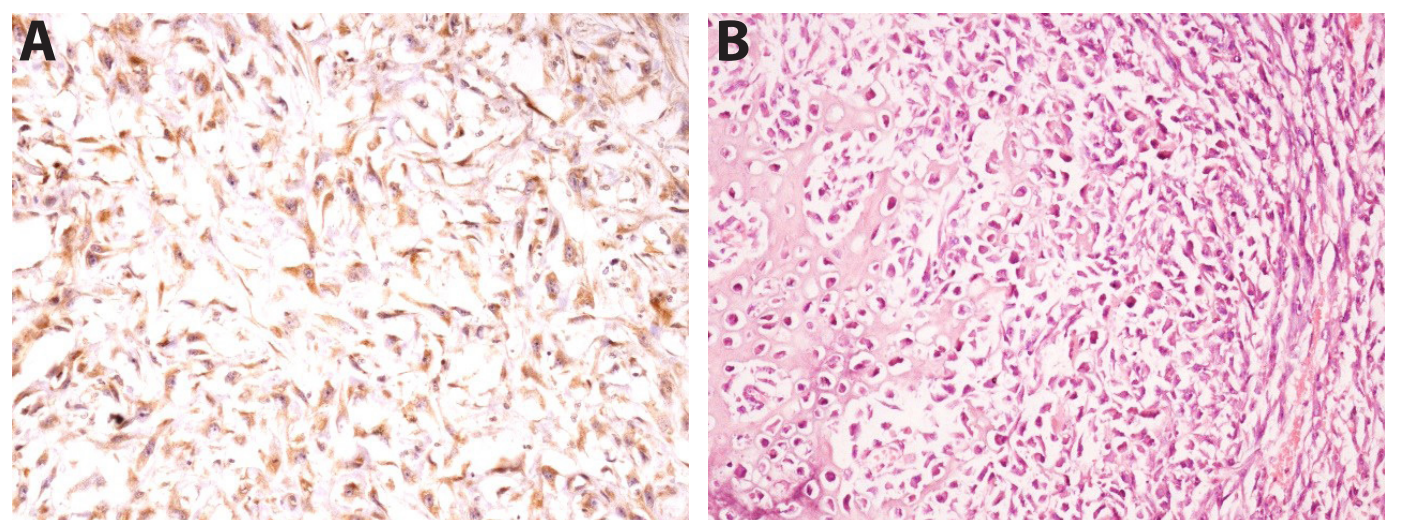

Figure 2 - Histomorphological aspect of gastrointestinal stromal tumor (GIST) and intestinal osteosarcoma in dogs. A. GIST, CD117 (c-KIT) positive immune reaction, Streptavidinbiotin-peroxidation by Harris haematoxylin. IHQ, 200 x, B. Histomorphological aspect of intestinal osteosarcoma in dogs. Hematoxylin and eosin, $200 \mathrm{x}$

The S100 protein is a typical marker of lesions originating from the myenteric nervous plexus, which is present mostly in neoplasms of neural origin, and absent in musclederived neoformations (CERIEL et al., 2007; HANAZONO et al, 2012). In $68 \%-73 \%$ of neurogenic GISTs positive immunoreactivity for S100 protein is observed (LAROCK; GINN, 1997; CERIEL et al., 2007; HAYES et al., 2013). CD34 antibody is a cell surface glycoprotein, and it was originally described in precursor cells of myeloid and lymphoid tissue in the bone marrow. In addition, $60 \%$ - $70 \%$ of all GISTs located in the ESOPHAGUS and rectum are CD34-positive in humans (GILLESPIE et al., 2011). There is no significant difference in CD34 expression between benign and malignant GISTs (GILLESPIE et al., 2011). Table 2 presents the summary of the recommended immunohistochemical panel for the diagnosis and differentiation of GIST (LEANDRO; SÁ, 2016).

Table 2 - Antibody panel recommended for the diagnosis and characterization of GIST - São Paulo - 2017 (adapted from LEANDRO; SÁ, 2016)

\begin{tabular}{|c|c|c|c|c|c|c|c|}
\hline \multicolumn{8}{|c|}{ Antibodies } \\
\hline Differentiation & Vimentin & CD117 & DOG-1 & S100* & SMA $^{\#}$ & Desmin & CK 20* \\
\hline GIST neurogenic & + & + & + & + & - & - & - \\
\hline GIST miogenic & + & + & + & - & + & + & - \\
\hline GIST anaplastic & + & + & + & - & - & - & - \\
\hline GIST mixed & + & + & + & + & + & + & - \\
\hline
\end{tabular}

* protein S100; ${ }^{*}$ SMA (smooth muscle actin), ${ }^{*}$ CK 20 (cytokeratin 20$)$

The main histopathological differential diagnoses for GIST are leiomyoma, leiomyosarcoma, poorly differentiated sarcoma, and peripheral nerve sheath tumor (HAYES et al., 2013). The immunohistochemical reaction is very useful in the differential diagnosis, since these neoplasms do not express c-KIT and DOG 1 (LAROCK; GINN, 1997; COHEN et al., 2003). It should be noted that the expression of c-KIT is not restricted to GIST, since positive immuno-tagging is also observed in melanoma, germ cell tumors, astrocytomas, seminomas, and angiosarcomas (MIETTINEN; LASOTA, 2001). It stands out that these neoplasias exhibit specific morphology and immunoreactivity for other antibodies that aid the definitive morphological diagnosis.

\section{Smooth muscle neoplasms}

Smooth muscle neoplasms involve animals with a mean age of 11.8 years for neoplasms located in the cecum and 10.3 years for neoformations that affect the stomach, duodenum, and jejunum (COHEN et al., 2003; FARESE et al., 2008; HAYES et al., 2013). Prevalence ranges from 12 - 120 cases / 10,000 dogs; in which the LM and the LMS consist of 10\%-30\% of all the gastrointestinal mesenchymal tumors that affect dogs (COHEN et al., 2003; LEIBMAN et al., 2003; PARK et al., 2007; FARESE et al., 2008).

Smooth muscle neoplasms are characterized by proliferation of elongated to fusiforms cells, arranged in long interlocking bundles. The cytoplasm of the neoplastic 
cells is eosinophilic with imprecise boundaries, the elongate nucleus has straight edges and features that resemble cigars, and the nucleolus is generally not clear. The high ratio of nucleus: cytoplasm, foci of necrosis, and haemorrhage may be present in the malignant form, as shown in figure 1A. The stromal can be dense and collagenous, well-vascularized or myxomatous, with cavity spaces and areas with few cells (MIETTINEN et al., 2001; HEAD, et al., 2002; FROST et al., 2003; PARK et al., 2007; FARESE et al., 2008).

Sometimes the differentiation between benign and malignant is challenging. Morphological criteria used for differentiation include count of mitosis figures, areas of necrosis, haemorrhage, and presence of angiolymphatic invasion in malignant cases. Thus, counts above 10 mitoses / field $400 \mathrm{x}$ are indicative of malignancy (LAROCK; GINN, 1997; HEAD, et al., 2002; COHEN et al., 2003; FARESE et al., 2008).

Macroscopically, LMS and LM are characterized by being large single formations, polypoid, larger than $5 \mathrm{~cm}$, with imprecise boundaries due to involvement of adjacent tissues, compromising the muscular and mucosal layers, may be located in the esophagus, jejunum, cecum, and colorectal portion (CERIEL et al., 2007; RUSSEL et al., 2007; CONSTANT et al., 2015; HOBBS et al., 2015). The occurrence of intestinal perforation, peritonitis, and subsequent sepsis can occur in 50\% of intestinal LMS in dogs (COHEN et al., 2003).

The immunohistochemical classification of LM / LMS is based on positive immunoexpression for vimentin, which is a specific marker for mesenchymal neoplasms, and immunomarker for smooth muscle actin (SMA) and desmin (RUSSEL et al., 2007). In well differentiated neoplasms it is possible to find strong reactivity for SMA and desmin, but weak for vimentin. In cases with poorly differentiated neoplasms the intensity of reactivity for vimentin is strong and for SMA is weak. This finding may suggest malignant neoplasm behavior (HAYES et al., 2013). It is important to note that in the smooth muscle neoplasias, the expression of c-Kit, DOG1, S100 protein, cytokeratin AE1/AE3, CD3, CD20, and CD79 are not observed (MIETTINEN et al., 2001; CERIEL et al., 2007; RUSSEL et al., 2007).

In humans, prognostic indicators for LMS include the immunohistochemical detection of the MDR1 gene, P-glycoprotein (P-gp), and multiple drug resistance protein-1 (MRP-1) (PLAAT et al., 2000). The expression of these proteins in humans is associated with multiresistance to several chemotherapeutic drugs, such as the anthracyclines, doxorubicin and epirubicin (PLAAT et al., 2000). Expression of MRP-1 proteins is less pronounced in LMS when compared to GIST cases in humans, suggesting that LMS may be more sensitive to conventional chemotherapeutic agents than GIST (PLAAT et al., 2000). In dogs the application of these prognosis immunomarkers is unknown.

At the time of diagnosis $16 \%$ to $37.5 \%$ of dogs with intestinal LMS have intra-abdominal metastases and the most affected sites are the liver, peritoneum, mesentery, or mesenteric lymph nodes (COHEN et al., 2003; RUSSEL et al., 2007; CONSTANT et al., 2015).

Several studies point to hypoglycemia as the main paraneoplastic syndrome of animals with abdominal LMS. Hypoglycemia results from the production of insulin-like hormone by neoplasia (BAGLEY et al., 1996). In addition, the high glucose demand due to high tumor metabolism combined with the decrease in hepatic gluconeogenesis secondary to hepatic metastasis damages are also factors that contribute to hypoglycemia. Polyuria and polydipsia are present in $36 \%$ of dogs with intestinal LMS, which develop nephrogenic diabetes insipidus (COHEN; POLF, 1999). Animals presenting with LM in cecum present a shorter survival time (mean of 7.5 months) when compared to the survival rate of neoplasms located in the stomach, jejunum, and duodenum, for which the survival period is 1.1 years (COHEN et al., 2003; FROST et al., 2003; RUSSEL et al., 2007; CONSTANT et al., 2015; HOBBS et al., 2015). Animals that have an early clinical diagnosis and are submitted to medical and surgical treatment tend to not relapse in $40 \%$ to $60 \%$ of cases and present higher survival rate (CRAWSHAW et al., 1998).

Comparison between the parameters adopted to measure the postoperative survival of human patients includes the mitotic index and the size of the neoformation (MIETTINEN et al., 2001). Formations larger than $5 \mathrm{~cm}$ may show malignant behavior and metastasis frequently, even when the tumor exhibits reduced numbers of mitoses per field (MIETTINEN et al., 2001).

\section{Neurogenic Neoplasms}

Gastrointestinal neurogenic sarcomas are uncommon and have been reported in dogs and horses (KIRCHHOF et al., 1996; SCHÖNIGER; SUMMERS, 2009). These neoplasias usually involve the cranial nerves, spinal nerve roots or subcutaneous tissue more frequently than the 
segments of the gastrointestinal tract (CAMPBELL et al., 2003). Neurogenic sarcomas are usually classified as neurofibrosarcoma and schwannoma (KIRCHHOF et al., 1996; HEAD et al., 2002). The World Health Organization has grouped neoplasms that originate from Schwann cells, fibroblasts or perineural cells, such as nerve sheath neoplasm that may be benign or malignant (HEAD et al., 2002; SCHÖNIGER; SUMMERS, 2009).

Animals with neoplasias of neurogenic gastrointestinal origin present an average age of 9 years old at the time of diagnoses. The small intestine is the main site of development and there is involvement of the submucosa and muscle layer (SCHÖNIGER; SUMMERS, 2009; HAYES et al., 2013).

Macroscopically this neoplasm is circumscribed, firm, and has smooth surface (HAYES et al., 2013). Histomorphologically they may present two distinct patterns named Antoni A and Antoni B. The first is the most common and is characterized by the proliferation of fusiform cells arranged in long or short parallel beams distributed in multiple directions (KIRCHHOF et al., 1996; HEAD et al., 2002; SCHÖNIGER; SUMMERS, 2009; HAYES et al., 2013). The cells have elongated, oval or fusiforms nuclei. The cytoplasm is eosinophilic and has poorly defined limits. In this pattern, the arrangement of nuclei is in parallel clusters (palisade) arranged concentrically around acellular areas composed of amorphous collagen, known as Verocay corpuscles (SCH6ONIGER; SUMMERS, 2009; HAYES et al., 2013). The nuclei are pleomorphic and hyperchromatic with a distinct basophilic nucleolus. The mitotic index is low. The morphological pattern Antoni B is less common and presents areas of low cellular density, formed by fusiform or rounded cells, freely organized in a loose myxomatous stroma (HEAD et al., 2002; SCHÖNIGER, SUMMERS, 2009; HAYES et al., 2013).

The immunohistochemical markers applied in the characterization of these neoplasms are vimentin, protein S-100, PGP 9.5, and glial fibrillating acidic protein (GFAP) presenting cytoplasmic reactivity (CAMPBELL et al., 2003; HAYES et al., 2013). These immunomarkers are expressed in a wide variety of tissues and have been recognized as markers to identify a neurogenic differentiation of mesenchymal neoplasms (HAYES et al., 2013). Neurogenic sarcomas that are vimentin and S-100 positive, and PGP 9.5 negative are associated with the morphological pattern Antoni B (CAMPBELL et al., 2003). Neurogenic sarcomas are negative for smooth muscle markers, SMA and desmin, c-Kit, epithelial marker, cytokeratin AE1/AE3, and CD3, CD20, and CD79 (SCHÖNIGER, SUMMERS, 2009; HAYES et al., 2013).

In general, reports in human medicine indicate that peripheral nerve sheath tumors that compromise the digestive tract have a benign behavior and do not present distant metastases, however, as the surgical treatment is delayed, they show a tendency to affect local mass, compromising adjacent tissues (LU et al., 2015). The behavior and survival of dogs presenting gastrointestinal peripheral nerve sheath neoplasms are unknown due to the lack of reports highlighting this information.

\section{Intestinal osteosarcoma}

Extra-skeletal osteosarcomas are malignant mesenchymal neoplasms producing osteoid matrix that occur in soft tissues and organs, and do not present concomitant bone or periosteal involvement. There is no definitive underlying cause, but some authors point out the participation of undifferentiated pluripotential cells in the etiopathogenesis of these neoplasms (LANGENBACK et al., 1998; DUFFY et al., 2017).

The extrahepatic osteosarcoma may present osteoblastic, chondroblastic, fibroblastic, osteochondroblastic, and histiocytic differentiation (LANGENBACK et al., 1998; MACKENZIE, et al., 2012). Osteoblastic osteosarcoma is the most common histological type, being reported in $63.6 \%$ of cases of extrahepatic canine osteosarcoma, mainly affecting the mammary gland, spleen, testicles, eyes, vagina, kidneys, and liver (LANGENBACK et al., 1998; URBIZTONDO et al., 2010; DUFFY et al., 2017).

The intestinal extraskeletal osteosarcomas are uncommon and mainly affect all the intestinal layers of the jejunum (PARDO et al., 1990; MACKENZIE, et al., 2012). Macroscopically, these neoplasms are large tumors, whose measurements vary from 2.5 to $30 \mathrm{~cm}$ in diameter with a mean of $12.7 \mathrm{~cm}$, which present irregular surfaces that extend from the intestinal muscle layers to the mucosa (LANGENBACK et al., 1998; URBIZTONDO et al., 2010; DUFFY et al., 2017). These tumors are characterized by polygonal mesenchymal cells with pleomorphic fusiform, with large vesicular nucleus and eosinophilic cytoplasm. There is production of osteoid matrix, as shown in figure $2 \mathrm{~B}$, which sometimes mineralizes forming bone trabeculae. This peculiarity is not always present in these tumors and calcification is not reactive or metaplastic. The number 
of mitosis figures per field is variable and can be high (PARDO et al., 1990; LANGENBACK et al., 1998; DUFFY et al., 2017).

Immunohistochemical characterization is limited in the case of osteosarcoma due to the absence of specific markers, but these tumors are positive for vimentin. The antiosteonectin antibody is poorly sensitive and can react with various cell types including active osteoblasts, immature osteocytes, fibroblasts, and epithelial cells (PARHAM, 2015; WEHRLE-MARTINEZ et al., 2016). Anti-osteopontin antibody also has low sensitivity, and although studies have shown expression in osteosarcomas, this antibody also presents immunoreaction in the epithelium of the gastrointestinal tract, gallbladder, pancreas, urinary, and reproductive tracts, salivary and sweat glands, as well as vascular endothelial cells, macrophages, and myoepithelial cells, and there is no immunostaining. in hematopoietic neoplasms (PARHAM, 2015; WEHRLE-MARTINEZ et al., 2016). The anti-osteocalcin antibody reacts with osteocytes of adult bone and presents positive immunostaining in $66.6 \%$ of cases of low-grade, well-differentiated osteosarcomas; therefore it is more specific when compared to osteonectin and osteopontin (WEHRLEMARTINEZ et al., 2016). In contrast, the immunostaining of osteocalcin is much lower in high-grade undifferentiated osteosarcomas, so its sensitivity is lower depending on the degree of differentiation of the neoplasia (PARHAM, 2015; WEHRLE-MARTINEZ et al., 2016).

On the other hand, the immunohistochemical panel is useful to determine the morphological origin and to differentiate the osteosarcomas from other mesenchymal, epithelial, and hematopoietic neoplasias that may present foci of bone matrix. Intestinal carcinomas are the most common gastrointestinal neoplasms in dogs, they are AE1/AE3 cytokeratin positive, negative vimentin, and may present areas of metaplastic production of the osteoid matrix secondary to the production of osteoinductive cytokines such as the $\beta$-transglobulin growth factor, fibroblasts growth factor, and insulin-like factors 1 and 2 (TURK et al., 1981).

Intra-abdominal osteosarcomas present an aggressive behavior and worse prognosis associated with a high mortality rate when located in the gastrointestinal tract and liver (LANGENBACK et al., 1998; URBIZTONDO et al., 2010; MACKENZIE, et al., 2012; DUFFY et al., 2017).

\section{Final considerations}

Table 3 summarizes the main references that address the anatomopathological characteristics of gastrointestinal neoplasias affecting dogs according to segment of the gastrointestinal tract, intestinal wall location, immunomarkers and survival after diagnosis.

Table 3 - Summary of the characteristics of the non-hematopoietic mesenchymal gastrointestinal neoplasms that affect dogs, second segment affected, involvement of the layers, immunomarkers, and survival after diagnosis in months - São Paulo $-2017$

\begin{tabular}{|c|c|c|c|c|}
\hline Parameters $^{1} \backslash$ Tumor $^{2}$ & GIST & LMS/LM & PNST & Osteosarcoma \\
\hline Segment & LI & E/ LI & SI & LI \\
\hline Layers of the organ & submucosa and muscular & muscular and mucosa & submucosa and muscular & all layers \\
\hline Vimentin & + & + & + & + \\
\hline C-KIT(CD117) & + & - & - & - \\
\hline DOG1 & + & - & - & - \\
\hline Smooth muscle actin & $+/-$ & + & - & - \\
\hline Desmin & $+/-$ & + & - & - \\
\hline S 100 & $+/-$ & - & + & - \\
\hline PGF 9.5 & - & - & + & - \\
\hline CD34 & $+/-$ & - & - & - \\
\hline CD3 & - & - & - & - \\
\hline CD79a & - & - & - & - \\
\hline CD20 & - & - & - & - \\
\hline Cytokeratin AE1/AE3 & - & - & - & - \\
\hline Survival & 11,6 months & $7,5-12$ months & No reports & $1-4$ months \\
\hline References & HAYES et al., 2013 & RUSSEL et al., 2007 & SCHONIGER; SUMMERS, 2009 & DUFFY et al., 2015 \\
\hline
\end{tabular}

${ }^{2}$ GIST (gastrointestinal stromal tumor); LMS (leiomyosarcoma); LM (leiomyoma); PNST (peripheral nerve sheath tumor); E (esophagus) SI (small intestine); LI (large intestine) 


\section{References}

BAGLEY, R. S.; LEVY, J. K.; MALARKEY, D. E. Hypoglycemia associated with intra-abdominal leiomyoma and leiomyosarcoma in six dogs. Journal of the American Veterinary Medical Association, v. 208, n. 1, p. 69-71, 1996.

BETTINI, G.; MORINI, M.; MARCATO, P. S. Gastrointestinal spindle cell tumours of the dog: histological and immunohistochemical study. Journal of Comparative Pathology, v. 129, n. 4, p. 283-293, 2003. doi: 10.1016/S0021-9975(03)00046-X.

CAMPBELL, L. K.; THOMAS, J. R.; LAMPS, L. W.; SMOLER, B. R.; FOLPE, A. L. Protein gene product 9.5 (PGP 9.5) is not a specific marker of neural and nerve sheath tumors: an immunohistochemical study of 95 mesenchymal neoplasms. Modern Pathology, v. 16, n. 10, p. 963-969, 2003. doi: 10.1097/01.MP.0000087088.88280.B0.

CERIEL, P. H. J. M.; TER HAAR, G.; VAN DER GAAG, I.; KIRPENSTEIJN, J. Reclassification of small intestinal and cecal smooth muscle tumors in 72 dogs: clinical, histologic, and immunohistochemical evaluation. Veterinary Surgery, v. 36, n. 4, p. 302-313, 2007. doi: 10.1111/j.1532950X.2007.00271.x.

COHEN, B.; POST, G. S. Nephrogenic diabetes insipidus in a dog with intestinal leiomyosarcoma. Journal of the American Veterinary Medical Association, v. 215, n. 12, p. 1818-1820, 1999.

COHEN, M.; POST, G. S.; WRIGHT, J. C. Gastrointestinal leiomyosarcoma in 14 dogs. Journal of Veterinary Internal Medicine, v. 17, n. 1, p. 107-110, 2003. doi: 10.1111/j.19391676.2003.tb01331.x.

CONSTANT, C. E.; POLF, H. D. What is your diagnosis? Journal of the American Veterinary Medical Association, v. 246, n. 1, p. 51-53, 2015. doi: 10.2460/javma.246.1.51.

CRAWSHAW, J.; BERG, J.; SARDINAS, J. C.; ENGLER, S. J.; RAND, W. M.; OGILVIE, G. K.; SPODNICK, G. J.; O'KEEFE, D. A.; VAIL, D. M.; HENDERSON, R. A. Prognosis for dogs with non lymphomatous, small intestinal tumors treated by surgical excision. Journal of the American Animal Hospital Association, v. 34, n. 6, p. 451-456, 1998. doi: 10.5326/15473317-34-6-451.
DAILEY, D. D.; EHRHART, E. J.; DUVAL, D. L.; BASS, T.; POWERS, B. E. DOG1 is a sensitive and specific immunohistochemical marker for diagnosis of canine gastrointestinal stromal tumors. Journal of Veterinary Diagnostic Investigation, v. 27, n. 3, p. 268-277, 2015. doi: $10.1177 / 1040638715578878$.

DUFFY, D.; SELMIC, L. E.; KENDALL, A. R.; POWERS, B. E. Outcome following treatment of soft tissue and visceral extraskeletal osteosarcoma in 33 dogs: 2008-2013. Veterinary and Comparative Oncology, v. 15, n. 1, p. 4654, 2017. doi: 10.1111/vco.12141.

FARESE, J. P.; BACON, N. J.; EHRHART, N. P.; BUSH, J.; EHRHART, E. J.; WITHROW, S. J. Oesophageal leiomyosarcoma in dogs: surgical management and clinical outcome of four cases. Veterinary and Comparative Oncology, v. 6, n. 1, p. 31-38, 2008. doi: 10.1111/j.14765829.2007.00134.x.

FLETCHER, C. D. M.; BERMAN, J. J.; CORLESS, C.; GORSTEIN, F.; LASOTA, J.; LONGLEY, J.; MIETTINEN, M.; O’LEARY, T. J.; REMOTTI, H.; RUBIN, B. P.; SHMOOKLER, B.; SOBIN, L. H.; WEISS, S. W. Diagnosis of gastrointestinal stromal tumors: a consensus approach. Human Pathology, v. 33, n. 5, p. 459-465, 2002. doi: 10.1053/hupa.2002.123545.

FROST, D.; LASOTA, J.; MIETTINEN, M. Gastrointestinal stromal tumors and leiomyomas in the dog: a histopathologic, immunohistochemical, and molecular genetic study of 50 cases. Veterinary Pathology, v. 40, n. 1, p. 42-54, 2003. doi: 10.1354/vp.40-1-42.

GILLESPIE, V.; BAER, K.; FARRELLY, J.; CRAFT, D.; LUONG, R. Canine gastrointestinal stromal tumors: immunohistochemical expression of CD34 and examination of prognostic indicators including proliferation markers Ki67 and AgNOR. Veterinary Pathology, v. 48, n. 1, p. 283-291, 2011. doi: 10.1177/0300985810380397.

GUILFORD, G. W.; STROMBECK, D. R. Neoplasms of the gastrointestinal tract, APUD tumors, endocrinopathies and the gastrointestinal tract. In: GUILFORD, G. W.; CENTER, S. A.; STROMBECK, D. R.; WILLIAMS, D. 
A.; MEYER, J. D. (Eds.). Strombeck's small animal gastroenterology. Philadelphia: Saunders, 1996. p. 519-531.

HANAZONO, K.; FUKUMOTO, S.; HIRAYAMA, K.; TAKASHIMA, K.; YAMANE, Y.; NATSUHORI, M.; KADOSAWA, T.; UCHIDE, T. Predicting metastatic potential of gastrointestinal stromal tumors in dog by ultrasonography. Journal of Veterinary Medical Science, v. 74, n. 11, p. 1477-1482, 2012. doi: 10.1292/ jvms.11-0553.

HAYES, S.; YUZBASIYAN-GURKAN, V.; GREGORYBRYSON, E.; KIUPEL, M. Classification of canine nonangiogenic nonlymphogenic, gastrointestinal sarcomas based on microscopic, immunohistochemical, and molecular characteristics. Veterinary Pathology, v. 50, n. 5, p. 779-788, 2013. doi: 10.1177/0300985813478211.

HEAD, K. W.; ELSE, R. W.; DUBIELZIG, R. R. Tumors of the alimentary tract. In: MEUTEN, D. J. (Ed.). Tumors in domestic animals. 4. ed. Ames: Iowa State Press, 2002. p. 431-459. doi: 10.1002/9780470376928.ch8.

HOBBS, J.; SUTHERLAND-SMITH, J.; PENNINCK, D.; JENNINGS, S.; BARBER, L.; BARTON, B. Ultrasonographic features of canine gastrointestinal stromal tumors compared to other gastrointestinal spindle cell tumors. Veterinary Radiology Ultrasound, v. 56, n. 4, p. 432-438, 2015. doi: 10.1111/vru.12253.

IRIE, M.; TAKEUCHI, Y.; OHTAKE, Y.; SUZUKI, H.; NAGATA, N.; MIYOSHI, T.; KAGAWA, Y.; YAMAGAMI, $\mathrm{T}$. Imatinib mesylate treatment in a dog with gastrointestinal stromal tumors with a c-kit mutation. Journal of Veterinary Medical Science, v. 77, n. 11, p. 1535-1539, 2015. doi: 10.1292/jvms.15-0096.

KIRCHHOF, N.; SCHEIDEMANN, W.; BAUMGÄRTNER, $\mathrm{W}$. Multiple peripheral nerve sheath tumors in the small intestine of a horse. Veterinary Pathology, v. 33, n. 6, p. 727-730, 1996. doi: 10.1177/030098589603300618.

LAROCK, R. G.; GINN, P. E. Immunohistochemical staining characteristics of canine gastrointestinal stromal tumors. Veterinary Pathology, v. 34, n. 4, p. 303-331, 1997. doi: $10.1177 / 030098589703400406$.
LANGENBACK, A.; ANDERSON, M. A.; DAMBACH, D. M.; SORENMO, K. U.; SHOFER, F. D. Extraskeletal osteosarcomas in dogs: a retrospective study of 169 cases (1986-1996). Journal of the American Veterinary Medical Association, v. 34, n. 2, p. 113-120, 1998. doi: 10.5326/15473317-34-2-113.

LEANDRO, R.M.; SÁ, L. R.M.Neoplasias gastrointestinais. In: JERICÓ, M. M.; KOGIKA, M. M.; ANDRADE NETO, J. P. (Eds.). Tratado de medicina interna de cães e gatos. Rio de Janeiro: Roca, 2015. p. 995-1003.

LEANDRO, R. M.; SÁ, L. R. M. Tumor estromal gastrointestinalem cães: estudoclínico-anatomopatológico. Arquivo Brasileiro de Medicina Veterinária e Zootecnia, v. 68 , n. 4 , p. $938-944$, 2016. doi: 10.1590/1678-4162-8767.

LEIBMAN, N. F.; LARSON, V. S.; OGILVIE, G. K. Oncology diseases of the digestive system. In: TAMS, T. R. (Ed.). Handbook of small animal gastroenterology. 2. ed. St. Louis: Saunders, 2003. p. 370-415.

LIEGL, B.; HORNICK, J. L.; CORLESS, C. L.; FLETCHER, C. D. Monoclonal antibody DOG1.1 shows higher sensitivity than KIT in the diagnosis of gastrointestinal stromal tumors, including unusual subtypes. The American Journal of Surgical Pathology, v. 33, n. 3, p. 437-446, 2009. doi: 10.1097/PAS.0b013e318186b158.

LU, C.; QIU, Y.; LU, X.; LI, G.; BU, H. Synchronous diffuse ganglioneuromatosis and multiple schwannomas of the colon: a case report and literature review. Experimental and Therapeutic Medicine, v. 9, n. 3, p. 733-736, 2015. doi: 10.3892/etm.2015.2212.

MACKENZIE, S.; HECHT, S.; SURA, P. A.; CRAIG, L. E. What is your diagnosis? extraskeletal osteosarcoma. Journal of the American Veterinary Medical Association, v. 240 , n. 7, p. $817-818$, 2012. doi: 10.2460/javma.240.7.817.

MIETTINEN, M.; FURLONG, M.; SARLOMORIKALA, M.; BURKE, A.; SOBIN, L. H.; LASOTA, J. Gastrointestinal stromal tumors, intramural leiomyomas, and leiomyosarcomas in the rectum and anus: a clinicopathologic, immunohistochemical, and molecular genetic study of 144 cases. The American Journal of Surgical Pathology, v. 25, n. 9, p. 1121-1133, 2001. 
MIETTINEN, M.; LASOTA, J. Gastrointestinal stromal tumors: definition, clinical, histological, immunohistochemical, and molecular genetic features and differential diagnosis. Virchows Archiv, v. 438, n. 1, p. 1-12, 2001. doi: 10.1007/s004280000338.

PARDO, A. D.; ADAMS, W. H.; MCCRACKEN, M. D.; LEGENDRE, A. M. Primary jejunal osteosarcoma associated with surgical sponge in a dog. Journal of the American Veterinary Medical Association, v. 196. n. 6, p. 935-938, 1990.

PARHAM, D. M. Immunohistochemical markers of soft tissue tumors: pathologic diagnosis, genetic contributions, and therapeutic options. Analytical Chemistry Insights, v. 10, p. 1-10, 2015. Supplement 1. doi: 10.4137/ACI.S32730.

PARK, C.-H, ISHIZUKA, Y.; TSUCHIDA, Y.; OYAMADA, T. Gastric pleomorphic leiomyosarcoma in a Shetland sheepdog. Journal of Veterinary Medicine Science, v. 69, n. 8, p. 873-876, 2007. doi: 10.1292/jvms.69.873.

PLAAT, B. E.; HOLLEMA, H.; MOLENAAR, W. M.; TORN BROERS, G. H.; PIJPE, J.; MASTIK, M. F.; HOEKSTRA, H. J.; VAN DEN BERG, E.; SCHEPER, R. J.; VAN DER GRAAF, W. T. Soft tissue leiomyosarcomas and malignant gastrointestinal stromal tumors: differences in clinical outcome and expression of multidrug resistance proteins. Journal of Clinical Oncology, v. 18, n. 18, p. 3211-3220, 2000. doi: 10.1200/JCO.2000.18.18.3211.

RUSSEL, K. R.; MEHLER, S. J.; SKORUPSKI, K. A.; BAEZ, J. F.; SHOFER, F. S.; GOLDSCHIMIDT, M. H. Clinical and immunohistochemical differentiation of gastrointestinal stromal tumors from leiomyosarcomas in dogs: 42 cases (1990-2003). Journal of the American Veterinary Medical Association, v. 230, n. 9, p. 1329-1333, 2007. doi: 10.2460/ javma.230.9.1329.

SCHÖNIGER, S.; SUMMERS, B. A. Localized, plexiform, diffuse, and other variants of neurofibroma in 12 dogs, 2 horses, and a chicken. Veterinary Pathology, v. 46, n. 5, p. 904-915, 2009. doi: 10.1354/vp.08-VP-0322-S-FL.

TURK, M. A. M.; GALliNA, A. M.; RUSSEL, T. S. Nonhematopoietic gastrointestinal neoplasia in cats: a retrospective study of 44 cases. Veterinary Pathology, v. 18 , n. 5, p. $614-620$, 1981. doi: 10.1177/0300985 88101800506 .

URBIZTONDO, R.; CHAPMAN, S.; BENJAMINO, K. Primary mesenteric root osteosarcoma in a dog. Veterinary Clinical Patholology, v. 39, n. 3, p. 377-380, 2010. doi: 10.1111/j.1939-165X.2010.00239.x.

WASHABAU, R. J. Neoplasia. In: WASHABAU, R. J.; DAY, M. J. (Eds.). Canine and feline gastroenterology. Amsterdam: Elsevier, 2013. p. 764-767.

WEHRLE-MARTINEZ, A. S.; DITTMER, K. E.; ABERDEIN, D.; THOMPSON, K. G. Osteocalcin and osteonectin expression in canine osteosarcoma. Veterinary Pathology, v. 53, n. 4, p. 781-787, 2016. doi: $10.1177 / 0300985815626574$.

ZAO, X.; YUE, C. Gastrointestinal stromal tumor. The Journal of Gastrointestinal Oncology, v. 3, n. 3, p. 189208, 2012. doi: 10.3978/j.issn.2078-6891.2012.031. 